\title{
The Effect of Sales Growth, Capital Expenditure, and Working Capital Efficiency on Indonesian-Listed-Consumer-Goods Firms' Financial Performance with Capital Structure as Moderating Variable
}

\section{Youlanda Githa Dovita, Andewi Rokhmawati*, Ahmad Fauzan Fathoni}

The Faculty of Economics and Business Universitas Riau, Pekanbaru, Indonesia

*Andewi.Rokhmawati@lecturer.unri.ac.id

\begin{tabular}{ll}
\hline Article Info & Abstract \\
\hline $\begin{array}{l}\text { Received }: 2019-01-01 \\
\text { Accepted }: 2019-01-15\end{array}$ & $\begin{array}{l}\text { This study aims to determine the effect of sales growth, capital } \\
\text { expenditure and working capital efficiency on financial performance } \\
\text { Published }: 2019-01-28\end{array}$ \\
\hline $\begin{array}{l}\text { which is moderated by the capital structure. The population in this } \\
\text { study was all consumer goods industry firms listed on the Indonesia }\end{array}$ \\
$\begin{array}{l}\text { Capital Expenditure, Working } \\
\text { Capital Efficiency, Capital }\end{array}$ & $\begin{array}{l}\text { Stock Exchange in 2014-2017. Sampling in this study was based on } \\
\text { purposive sampling and obtained as many as 35 firms. The } \\
\text { analytical method used was Partial Least Square (PLS) analysis. The } \\
\text { Structure, Financial Performance }\end{array}$ \\
& $\begin{array}{l}\text { results showed that sales growth and capital expenditure do not } \\
\text { significantly affect capital structure; working capital and capital } \\
\text { structure has a positive and significant effect on financial } \\
\text { performance. Meanwhile, as a moderating variable, capital structure } \\
\text { is not able to moderate the influence of sales growth on financial } \\
\text { performance. Capital structure weakens the effect of capital } \\
\text { expenditure and efficiency working capital on financial } \\
\text { performance. }\end{array}$ \\
&
\end{tabular}

\section{Introduction}

Trade liberalization provides flexibility for the entry of imported goods, especially consumer goods to Indonesia; so that, this may slow down the growth of domestic industries. Competition in the Indonesian manufacturing industry is getting tougher. According to data from the Indonesian Ministry of Industry (Kementerian Perindustrian, 2013), the manufacturing index, which are consists of the consumer goods sectors, basic industry and various industries which increased 9.37\% since the beginning of the year until August 2, 2013. Manufacturing was mainly supported by the consumer sector which grew $28 \%$ and the performance of the consumer sector was also high (Kementerian Perindustrian, 2013).

According to Rozuli (2017), trade liberalization becomes the main threat of the consumer goods sector because the government widens the import facet of consumer goods. In 2013 to 2014, the consumer goods import has reached the level of 5,599.10 tons and in 2015 decreased to the level of 4,929.20 tons. However, in 2016 imports of consumer goods increased by 960.30 tons so that the total imports in 2016 were 5,889.50 tons. Adhinegara (2017) said that when looking at the profile of 2016 economic growth in more detail, there are approximately nine business sectors in Indonesia down. Industrial sector performance declined from 4.52 percent in the third quarter to 3.36 percent in the fourth quarter of 2016. Meanwhile, on an annual basis, the growth of the industrial sector dropped to 4.29 percent compared to 2015 at 4.33 percent. Another impact of trade liberalization is the increasing number of firms in the industry; thus driving the industry becomes more competitive. The increase in the level of competitiveness has an impact on the level of profits obtained by the firms. In addition to trade liberalization, technology also affects firms' competitiveness. By using new technology, firms 
can produce goods more efficiently and are able to compete with other firms so that they can generate more profit. One indicator to measure firms' profits is Return on Assets (ROA). Return on Assets measures a firm's ability to utilize its assets to make a profit. The greater the ROA means the higher the profitability of the firm. The following data illustrates the development of the level of corporate profitability from the consumer goods industry in the period 2013-2016 as seen from Return on Assets (ROA).

Table 1. Return on Asset

\begin{tabular}{lllll}
\hline & $\mathbf{2 0 1 3}$ & $\mathbf{2 0 1 4}$ & $\mathbf{2 0 1 5}$ & $\mathbf{2 0 1 6}$ \\
\hline ROA $(\%)$ & 12.86 & 11.14 & 11.54 & 11.01
\end{tabular}

Source: Computed data based on firms' annual and financial report published in IDX (2017)

The firms' financial performance measured in the average value of Return on Assets has a declining trend. This decrease in profitability may be caused by an increase in assets not followed by an increase in net income where the total value of assets from 2013-2016 has increased each year with the total assets per year of IDR 4,456,865 in 2013; IDR 4,947,874 in 2014; IDR 5,666,140 in 2015; and IDR 6,015,807 in 2016 (Indonesian Stock Exchange, 2017).

The decline in the profitability growth may be because the firms are not able to compete. According to Sari (2013), there are several ways to increase a firm's competitiveness: First, increase sales by using sophisticated technology. By using that sophisticated technology, firms are able to produce goods with good and consistent quality in which this allows firms to minimize their production costs. This eventually can increase the firm's sales. Second, the use of the technology may allow firms to work at an economic scale so that firms can minimize production costs per unit so that this can improve firms' competitiveness. Third, the improvement of working capital management leads firms to reduce costs. In carrying out operational activities, firms require working capital in which working capital may be financed from equity and debt. If there is an excess or lack of funds, this will affect the level of firms' profitability. Fourth, managers need the availability of sufficient funds to finance their expansion. The availability of funds can be from internal that is from equity and external sources of the fund that is from debts.

Many studies have been conducted in the literature on the relationship between sales growth and capital expenditure on ROA. The generally examine the direct effect of the relationship. However, few studies have been conducted to examine the moderating effect of capital structure direct included in the model of the relationship between sales growth and capital expenditure on ROA. Furthermore, there also few studies that include working capital efficiency in a research model and then examining the moderating effect of capital structure on the effect of working capital efficiency on ROA. These moderating effects are the gap that intends to be filled by this research. Hence, the contribution of this research is laid on the empirical results of these moderating effects.

Based on the background described above, the purpose of this study is to analyze and provide empirical evidence regarding the effect of sales growth, capital expenditure, working capital efficiency on the financial performance and capital structure as moderating variables. This study covers Consumer Goods firms listed on the Stock Exchange for the period 20142017. 


\section{Literature Review}

\section{Theoretical basis}

\section{Resource-Based Theory}

Resource-based theory was pioneered by Penrose (1959). This theory considers the firm as a collection of resources and capabilities in managing the resources owned by the firm. Resourcebased theory believes that firms will achieve excellence if they have superior resources.

\section{Pecking Order Theory}

This theory was first introduced by Donaldson (1961), while the Pecking Order Theory was conducted by Myers and Majluf (1984). In the perspective of pecking order theory, a capital structure can be ordered from the cheapest cost of capital to the most expensive one. Firms are more likely to choose the cheapest source of funding. The cheaper fund is from internal rather than external. If the internal fund is not enough, firms can find funding from external by following the capital cost order of funding source. Debt is the second choice after internal funding sources and if the firm still needs funds, it may issue common stock (external equity). Pecking order theory refers to firms that aim to maximize the prosperity of the owner of the firms. Pecking order theory predicts that external debt funding is based on internal funding deficits.

\section{Trade-off Theory}

The trade-off theory is a capital structure theory which states that firms may exchange tax benefits because firms use debts for problems caused by potential bankruptcy because firms use debts (Brigham \& Houston, 2016). The trade-off theory assumes that the firm's capital structure is the result of a trade-off of tax profits by using debt with costs that will arise as a result of using the debt.

Firms with high levels of profitability will certainly try to reduce taxes by increasing the debt ratio so that the additional debt will reduce taxes. The trade-off theory shows that the value of a firm with debt will increase with increasing levels of debt. The use of debt will increase the value of the firm but only to a certain point. After that point, the use of debt actually decreases the value of the firm.

\section{Firm Performance}

Performance is the achievement of the activity implementation in order to realize the firm's goals, where one of the important goals is to maximize shareholder wealth through increasing corporate value (Brigham \& Houston, 2016). According to Ikatan Akuntan Indonesia (2007) financial performance is the firm's ability to manage and control the resources it has.

\section{Capital Structure}

According to Brigham and Houston (2016), capital structure is a combination of debt and equity in the firm's long-term financial structure. Capital structure is an important issue for firms. The bad capital structure will have a direct effect on the financial position of the firm, especially with the existence of a very large debt that will burden the firm to achieve its goal. The optimal capital structure is a capital structure that optimizes the balance between risks and returns so as this may maximize stock prices (Brigham and Houston, 2016).

\section{Sales Growth}

Sales growth shows the level of absorption of market demand by firms. The higher sales growth means firms can meet market demand that accordingly firm sales will increase (Nugraha \& 
Haryanto, 2016). By using the ratio of sales growth, firms can see their sales trend from year to year. Sales must cover costs so that the firms can increase their profits.

\section{Capital Expenditure}

Capital expenditure is costs incurred in order to obtain fixed assets, to improve operational efficiency, to increase the productive capacity of fixed assets, and to extend the useful life of fixed assets. These costs are usually a large amount, not often occur, not charged directly as an expense in the income statement, but capitalized first as a fixed asset on the balance sheet, because this expenditure will benefit the firm in a long run (Kalungan, Ilat, \& Gamaliel, 2017).

\section{The Efficiency of Working Capital}

According to Brigham and Houston (2016), working capitals are all short-term assets or current assets such as cash, securities that can be traded, inventories and accounts receivable. Keown, Martin, Petty, and Scott-Jr (2010) stated that working capital is the firm's total investment in current assets or assets expected to be converted into cash within one year or less than one year. The efficiency of working capital can be seen from working capital turnover, accounts receivable turnover, and inventory turnover (Wibowo \& Wartini, 2012).

\section{Previous Research}

Research on corporate performance has been carried out. Some of them are research conducted by Jatismara (2011) which examines the effect of sales growth on return on firm assets. The results of this study indicate that sales growth has a positive and significant effect on return on assets, which means that the higher the sales growth, the higher the level of profit gained from sales activities, the greater the return on assets obtained. Conversely, research conducted by Nugraha and Haryanto (2016) states that sales growth does not affect the return on assets, which means that firms with large sales growth do not always have higher ROA.

Andrian (2012) conducted a study on the effect of capital expenditure on profitability which showed that capital expenditure had an influence on the profitability of the firm, where capital expenditure was able to expand business opportunities and would have an impact on increasing the profitability of the firm. While the research conducted by Asror (2016) stated that capital expenditure does not affect the firm's performance.

Ainiyah (2016) research on the effect of working capital efficiency on firm performance states that working capital efficiency has a significant effect on profitability, which means that the receivable turnover period depends on the length of time stipulated in the credit payment terms, so that the longer the credit payment terms mean the longer the working capital is tied to the receivables and means the smaller the turnover rate of accounts receivable in one period and vice versa the shorter the payment terms of credit, the shorter the level of bonded working capital in accounts receivable so that the accounts receivable turnover rate in one period is greater. Aprilia (2017) stated that accounts receivable turnover has a negative and significant effect on profitability. If accounts receivable turnover is high, this will result in a decrease in the firm's profitability.

Research on the effect of capital structure on firm performance has been carried out by Jatismara (2011) stating that DER has a negative and significant effect on ROA. That is, the greater the proportion of debt used for the capital structure of a firm, the less likely the rate of profit will be obtained. This is because the bigger the debt, the higher the interest cost. Wibowo and Wartini (2012) stated that debt does not affect ROA, because firms may not depend solely on debt, so to increase profitability the firm does not need to increase the amount of its debt. 


\section{Hypothesis Development}

\section{Sales Growth and Firm Performance}

Resource-Based Theory considers the firm as a collection of resources and capabilities in managing the resources owned by the firm. The firm's ability to manage resources well can create competitive advantages so that it can create value for the firm. Sales are the spearhead of a firm. Proper sales forecasts are needed, so the firm can prepare everything needed for the production process.

By using the ratio of sales growth, firms can find out the sales trend for their products from year to year. Brigham and Houston (2016) state that sales must be able to cover costs so that it will increase profits. Hence, the firm can determine the steps to be taken to anticipate the possibility of rising or falling sales in the coming years. From the explanation above, we can take the following hypothesis:

\section{Ha1: Sales Growth has an effect on ROA}

\section{Capital Expenditure and Firm Performance}

According to resource-based theory, firms will excel in business competition and obtain good financial performance by owning, controlling and utilizing important strategic assets, both tangible assets and intangible assets (Untara, 2014). To carry out operational activities, firms need investment or capital expenditure in the form of tangible assets such as purchasing and updating existing facilities so that the firm is able to deal with competition. Investment is expected to provide the profit that it can be measured as return on assets. If the return on firm assets goes up, it can be concluded that the firm is successful in investing capital. However, if the opposite occurs where the return on assets falls, it can be concluded that the firm failed in investing capital. From the explanation above, we can take the following hypothesis:

\section{Ha2: Capital Expenditure affects ROA}

\section{Working Capital Efficiency and Firm Performance}

The firm's ability to generate profits by managing accounts receivable efficiently can be seen from the turnover of accounts receivable. Account receivable turnover shows how long a firm collects receivables in one period where the funds invested in the receivables by the firm switch to cash. According to Kasmir (2010), the higher the ratio reveals that the working capital invested in accounts receivables is lower and of course this condition is good for the firm. That is, high accounts receivable turnover will switch to cash which will be used by firms in production to meet consumer demand so that the condition can affect profitability. This is in line with the research conducted by Ainiyah (2016) which states that working capital efficiency has a positive and significant effect on profitability. From the explanation above, we can take the following hypothesis:

\section{Ha3: Working Capital Efficiency has an effect on ROA}

\section{Capital Structure and Financial Performance}

The firm's policy to use a great number of debts affects the profits obtained by the firm. This is because the use of excessive debt can increase the failure risk of corporate. The higher the risk of a firm, the higher the level of profitability expected in return for high risk and vice versa the lower the risk of the firm, the lower the level of profitability expected in return for low risk.

Pecking order theory can explain why firms that have a high level of profit actually have a smaller debt level. The small debt level is not because the firm has a small debt level target, but because they do not need external funds. High-profit rates make their internal funds 
sufficient to meet their investment needs. If the level of debt changes the profitability of a firm will also change. But these changes have two sides. First, the increase in debt will also increase profitability and vice versa the decline in debt also decreases profitability. Second, the increase in debt will reduce profitability and decrease in debt will increase profitability (Hazmi, 2017). From the explanation above, we can draw the following hypothesis:

Ha4: Capital Structure affects ROA

\section{Sales Growth and Firm Performance Moderated by Capital Structure}

Pecking order theory has the purpose of maximizing the prosperity of the owner of the firm. A firm with lower risk is a firm that has stable sales growth. We can know the success or failure of a firm can be seen through sales volume. When sales growth decreases, profitability may decrease as well. If in this condition, firms use a high level of debts, the debts will strengthen the effect. In other words, the magnitude of the decrease will enlarge. From the explanation above, we can take the following hypothesis:

Ha5: Capital structure moderates the effect of sales growth on ROA

\section{Capital Expenditure and Firm Performance Moderated by the Capital Structure}

In resource-based theory, one of the factors that might be able to support business competitiveness is the cost of capital. Firms can invest or upgrade existing facilities or assets. To support their operations, firms need more funds to be able to renew or to upgrade their existing assets. Firms can use internal or external funds to invest in capital expenditures so that upgraded assets or facilities are expected to reduce costs and improve efficiency and are expected to improve firm performance. From the explanation above, we can draw the following hypothesis:

Ha6: Capital structure moderates the effect of capital expenditure on ROA

\section{Working Capital Efficiency and Firm Performance Moderated by Capital Structure}

Pecking order theory explains that firms are more likely to choose funds from internal rather than external firms and debt is external funding source that becomes the second choice after internal funding sources. Efficient capital turnover is able to control the operational costs of the firm. Account receivable turnover shows how long the collection of receivables is in a certain period that the funds invested in the receivables by the firm become cash again (Aprilia, 2017). Kasmir (2010) said that the higher ratio shows that the working capital invested in receivables is lower and of course this condition is good for the firm. Firms often finance their working capital from debts. As it is acknowledged that the higher level of debts may increase profit or the lower level of debts may reduce profit because firms miss their business opportunity. In contrast, the increase in the level of debts may decrease profit because the benefit from tax saving and the incremental of benefit are not able to cover costs resulted from increasing used debts (such as an increase in interest and costs associated with financial distress or bankruptcy); vice versa. From the explanation above, we can draw the following hypothesis:

Ha7: Capital structure moderates the effect of working capital efficiency on ROA 
Based on the explanation above, a research model can be drawn as follows:

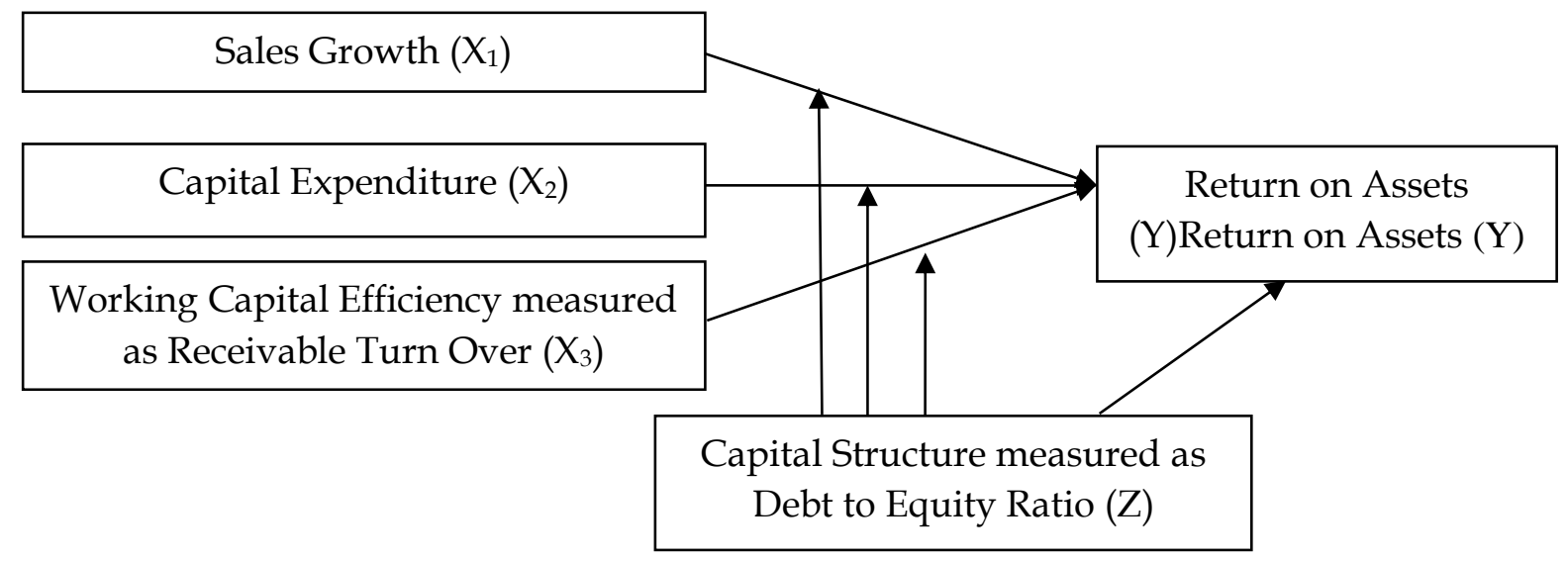

Source: Developed by the authors, 2018

\section{Research Methods}

Data

The population in this study is all consumer goods firms that are listed in the Indonesia Stock Exchange (IDX) in 2014-2017, with the population of 38 firms. This study uses a purposive sampling method to choose the sample in which the purposive sampling method is based on a particular assessment of some characteristics of the sample members adjusted for the purpose of the study. The sample in this study numbered to 35 firms. This study uses secondary data obtained from the financial report provided by the firms.

\section{Operational Definition of Variables and Variable Measurements}

The dependent variable used in this study is firm financial performance. Financial performance is firms' achievement of activity implementation to realize the firms' goals. In measuring financial performance, this study uses Return on Assets (ROA) that measures the ability of a firm to earn profits in a certain period. Brigham and Houston (2016) stated that ROA is the ratio of net income to total assets.

$R O A=\frac{\text { Earning After Tax }}{\text { Total Assets }}$

The independent variables in this research include sales growth, capital expenditure, and working capital efficiency. Sales growth shows sales activities measured from net sales. Sales growth can be calculated by implementing this following formula (Barus \& Leliani, 2013):

Sales Growth $=\frac{\text { Sales }_{t}-\text { Sales }_{t-1}}{\text { Sales }_{t-1}}$

Capital expenditure (CAPEX) is an expense made by a firm to obtain fixed assets. Rokhmawati (2017) stated that the fixed assets cover Plant, Property, and Equipment (PPE). In this study, capital expenditure is measured as the growth of capital expenditure in which capital expenditure is measured as the ratio of PPE divided by total assets as it is measured by Ilma, Amin, and Afifudin (2018). Hence, the measurement can be seen as follows: 


$$
\begin{aligned}
& \text { CAPEX }=\frac{\text { Net PPE }(\text { Fixed Assets })}{\text { Total Assets }} \\
& \text { CAPEX }=\frac{\text { Capex } x_{t}-\text { Cape }_{t-1}}{\text { Capex }_{t-1}}
\end{aligned}
$$

Working capital efficiency can be seen from working capital turnover, accounts receivable turnover, and inventory turnover (Wibowo \& Wartini, 2012). In this study, the efficiency of working capital can be measured using the accounts receivable turnover ratio. According to Kashmir (2010), receivable turnover is a ratio used to measure how many times the funds invested in these accounts rotates in one period. The formulas used to look for accounts receivable turnover are as follows (Rokhmawati, 2016):

Receivable turn over $=\frac{\text { Sales }}{\text { Receivables }}$

The moderating variable in this study is capital structure calculated as Debt to Equity Ratio. Capital structure is a comparison between total debt and equity. The optimal capital structure is a capital structure that optimizes the equilibrium between risks and returns so as to maximize stock prices (Brigham \& Houston, 2016). The capital structure of a firm can be measured by comparing the total debt with total equity.

$D E R=\frac{\text { Total debts }}{\text { Equities }}$

\section{Data Analysis}

This study uses the partial least square (PLS) with WarpPLS to analyze the data. This research uses PLS because although we have tried a various method to transform the data to get the normal residual of regression, the data is still not normal. Furthermore, the data still does not meet the classic assumption (normality, multicollinearity, heteroscedasticity, and autocorrelation) as it is required in the regression based on ordinary least square (OLS).

This article provides descriptive statistics to give a portrayal of the data that cover the mean, standard deviation, maximum and minimum values of the data. Descriptive statistics are useful to provide an overview of the distribution and behavior of the sample data (Ghozali, 2016). Then, the evaluation of the structural model (inner model) is provided. This model provides the model fit, path coefficient, and $\mathrm{R}^{2}$. Before analyzing the path coefficient significance and $\mathrm{R}^{2}$, the model should be checked for the fit of the model. The fit model test is used to determine whether a model has a match with the data. In the fit model test, there are three test indices must be met, namely average path coefficient (APC), average R-squared (ARS) and average variance factor (AVIF) with criteria:

1. Average path coefficient (APC) has a value of $P<0.05$.

2. Average R-squared (ARS) has a value of $\mathrm{P}<0.05$.

3. Average block Variance Inflation Factor (AVIF) has a value of $<5$ and ideally 3.3 .

After that, a hypothesis test can be conducted. From the test result, it can be seen the direction of the relationship between the independent variable as well as moderating variable and dependent variable. The results provide path coefficients and the significance level which is then we can conclude the relationship between independent variables as well as moderating variable 
and dependent variable. The level of significance used in this study is 5\%. Based on the explanation above, a hypothesis can be accepted or rejected based on the following criteria:

$P$-value $>0.05$, then $\mathrm{H} 0$ is accepted

$P$-value $<0.05$, then $\mathrm{H} 0$ is rejected and $\mathrm{Ha}$ is accepted

\section{Results and Discussion}

\section{Results}

Descriptive statistics provide the mean, standard deviation, maximum and minimum values of sales growth, capital expenditure, receivable turnover, financial performance (ROA) and capital structure (DER) as moderating variables. The numbers can be seen in Table 2 as follows:

Table 2. Descriptive Statistics Test Results

Descriptive Statistics

\begin{tabular}{llrrrr}
\hline & N & $\begin{array}{c}\text { Minimum } \\
\text { in percent }\end{array}$ & $\begin{array}{c}\text { Maximum } \\
\text { in percent }\end{array}$ & $\begin{array}{c}\text { Mean } \\
\text { in percent }\end{array}$ & Std.Deviation \\
\hline Sales Growth & 140 & 31.22 & 36.34 & 32.1056 & .41551 \\
CAPEX & 140 & 31.32 & 35.30 & 32.0558 & .33652 \\
Working Capital Efficiency & 140 & 32.58 & 99.16 & 42.6838 & 10.08017 \\
Capital Structure & 140 & .96 & 45.98 & 32.7866 & 3.08907 \\
Financial performance & 140 & 15.29 & 85.00 & 42.0224 & 11.47077 \\
Valid N (listwise) & 140 & & & & \\
\hline
\end{tabular}

Source: computed data

After performing the descriptive statistics, we evaluate the fitness of the research model by checking the indices of the results that are provided in Table 3. Furthermore, Figure 1 provides the model diagram of this research model.

Table 3. Model Fit Test

\begin{tabular}{lcccc}
\hline Fit and Quality Indices Model & Index & P values & Criteria & Information \\
\hline Average path coefficient (APC) & 0.200 & $<0.001$ & $\mathrm{P}<0.05$ & Accepted \\
$\begin{array}{l}\text { Average } \text { - } \text {-squared (ARS) } \\
\begin{array}{l}\text { Average Adjusted } R \text { - } \\
\text { squared (AARS) }\end{array}\end{array}$ & 0.220 & $<0.001$ & $\mathrm{P}<0.05$ & Accepted \\
Average block VIF (AVIF) & 0.179 & $<0.001$ & $\mathrm{P}<0.05$ & Accepted \\
\hline
\end{tabular}

Source: computed Data 
Figure 1. Model Diagram of the Research

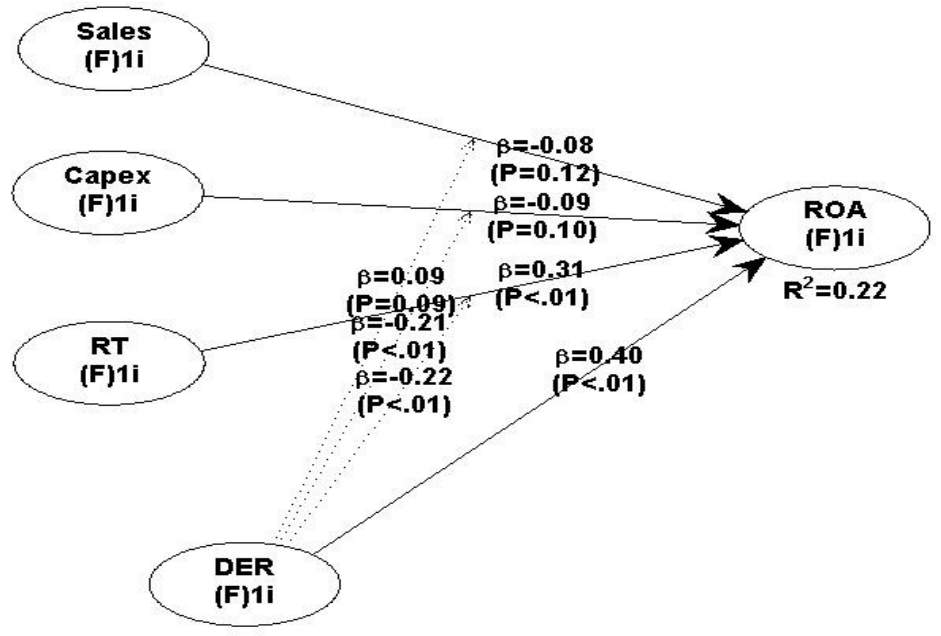

Source: WarpPLS 6.0 Processed Data

From the results, the magnitude of the R square is 0.220 . This shows that the magnitude of the influence of the independent variable sales growth, capital expenditure, receivable turnover and capital structure as moderating variables on Return on Assets which can be explained by this equation is $22 \%$, while $78 \%$ is influenced by other factors that are not included in the regression model.

After checking the fitness of the model, we analyze the path coefficient and the P values to evaluate the acceptance and rejection of the proposed hypothesis. Table 4 provides the data of path coefficient, $\mathrm{P}$ values and $\mathrm{R}$ square of research variables: sales growth, capital expenditure, receivable turn over and ROA with DER as a moderating variable

Table 4. Data of Path Coefficient, P Values and R Square of Research Variables (Sales Growth, Capital Expenditure, Receivable Turnover and ROA with DER as a Moderating Variable

\begin{tabular}{lccc|}
\hline Inter-Variable Influence & Path Coefficient & P Values & R Square \\
\hline SALES $\rightarrow$ ROA & $-0,080$ & 0.118 & 0.220 \\
CAPEX $\rightarrow$ ROA & $-0,085$ & 0.103 & 0.220 \\
$\mathrm{RT} \rightarrow$ ROA & 0.311 & $<0.001$ & 0.220 \\
DER $\rightarrow$ ROA & 0.398 & $<0.001$ & 0.220 \\
DER *SALES $\rightarrow$ ROA & 0.091 & 0.088 & 0.220 \\
DER*CAPEX $\rightarrow$ ROA & -0.211 & 0.001 & 0.220 \\
DER *RT $\rightarrow$ ROA & -0.223 & $<0.001$ & 0.220 \\
\hline
\end{tabular}

Source: WarpPLS 6.0 Processed Data

Based on the table above, it is known that the relationship between sales growth, capital expenditure, receivable turnover, and DER as moderating variables on ROA can be presented in the following equation:

ROA = -0,080 SALES - 0,085 CAPEX + 0,311 RT + 0,398 DER + 0.091 DER*SALES -

$0,211 \mathrm{DER} * \mathrm{CAPEX}-0,223 \mathrm{DER} * \mathrm{RT}$ 


\section{Discussion}

\section{The Effect of Sales Growth on ROA}

The statistical results show that sales growth has a negative and insignificant effect on financial performance. The negative sign means that the increase in sales is likely to reduce the firms' ROA. In contrast, the decrease in sales of the firms is likely to increase ROA, but the effect is not significant. The insignificance of the effect of sales growth on ROA may be caused by some reason. Firstly, the increased sales growth accompanied by the increased costs such as operating costs that is followed by the increase in asset growth lead to the decrease in ROA. This is because the profits obtained from sales are used to cover costs incurred in the firm operational activities so that this impact on the decrease in ROA. Furthermore, the insignificant influence might be that sales growth is not a major factor affecting firms ROA. According to Ainiyah (2016), other factors that can influence profitability are receivable turnover and debt to equity ratio. The results of this study are consistent with research conducted by Nugraha and Haryanto (2016) which stated that sales growth does not have a significant effect on return on assets.

\section{Effect of Capital Expenditure Growth on ROA}

The statistical results show that capital expenditure has a negative and not significant effect on ROA. A negative sign means that the increase in firms' capital expenditure growth is likely to reduce the firms' ROA. Whereas, the decrease in capital expenditure growth is likely to enhance the firms' ROA, but the effect is insignificant. The insignificance of the effect of capital expenditure growth on ROA may be caused by firstly, if the utilization of fixed assets purchased from capital expenditure is not adequately efficient, then the fixed costs per unit of product will increase. This clearly affects the competitiveness of the firms' products in the market, so that it will have an impact on firms' ROA. Second, the mistake in choosing fixed assets will have an adverse effect on the costs per unit, and the selling price. Accordingly, the firms' profit will decline as the firms' competitiveness decreases. The results of this study are in line with the research conducted by Asror (2016) which stated that capital expenditure does not have a significant effect on the firm's financial performance, and the results of this study are not in accordance with Andrian's research (2012) which states that capital expenditure has a significant effect on financial performance.

\section{Effect of Receivable Turnover on ROA}

Statistical results show that receivable turnover has a positive and significant effect on ROA. A positive sign means that the increase in receivable turnover will increase firms' ROA. On the contrary, the decrease in receivable turnover will significantly reduce the firms' ROA. The significant effect of receivable turnover on ROA is caused by the increased credit sales where the credit can be collected in a short time and the bad debts are low, this will allow firms to receive their cash from their receivable account in a short time so that the period of payment of receivables is faster. Accordingly, firms can reduce their costs of working capital so that firms' profitability will increase. The results of this study are supported by research conducted by Ainiyah (2016), Wibowo and Wartini (2012) which states that working capital efficiency has a significant effect on profitability.

\section{Effect of DER Growth on ROA}

Statistical results indicate that the capital structure growth has a positive and significant effect on ROA. A positive sign means that the increase in the use of debt will increase the firms' ROA. Conversely, the decrease in the use of debt will reduce the firms' ROA. The significant effect of DER growth on ROA may be caused by firstly, firms are able to utilize debts to finance their 
business efficiently so that it generates profits. Secondly, the use of debt provides benefits because of the reduction in tax payments due to interest on debt; therefore the firm should use debt in its capital structure. Thirdly, this result also implies that the current level of debt ratio used by firms is still at a safe level. Hence, the increase in debts still provides profit for firms. The results of this study are in line with Wahyuni's research (2012) which stated that the capital structure has a positive and significant effect on profitability. Hazmi (2017) also stated that the use of debt has a significant effect on firm profitability.

\section{The Effect of Sales Growth on ROA Moderated by DER}

The statistical results indicate that the sales growth which is moderated by DER has an insignificant effect on ROA. This shows that DER does not moderate the influence of sales growth on ROA. Optimal capital structure is a composition of debt and capital that is at the most appropriate and most financially profitable for firms. The use of external funds might have an influence on the relationship between sales and firms' ROA. The existence of additional debts will support firms to finance the expansion of firms' sales that eventually might increase sales growth. However, based on the result of the effect of ROS growth on ROA is negative despite insignificant. This means that the increase in sales growth is not followed by the increase in ROA. This may be because firms have to bear a high selling cost so that the profit cannot cover the high selling costs. By employing additional debts, firms must pay a higher interest so that this will reduce firms' ROA. Nevertheless, the level of DER seems at the safe level so that the benefit of adding debts can offset the firms' selling costs. Hence, DER does not moderate the effect of sales growth on firms ROA.

\section{The Effect of Capital Expenditure on ROA Moderated by DER}

Statistical results show that capital expenditure moderated by DER has a negative and significant effect on ROA. The result shows that DER weakens the negative effect of capital expenditure on ROA. This means that the use of debt will reduce the magnitude of the influence of capital expenditure on ROA. It can be explained as follows. The use of debts to renew or to utilize fixed assets will affect firms' ROA. Investment in fixed assets generally requires large amounts of funds. The use of debts will increase interest so that this will reduce firms' ROA.

Optimal capital structure is a composition of debt and capital that is at the most appropriate and most financially profitable for firms. The use of external funds might have an influence on the relationship between capital expenditure growth and firms' ROA. The existence of additional debts will support firms to finance their capital expenditure that eventually will increase total assets and from the increased assets, firms may gain higher revenues. However, based on the result of the effect of capital expenditure growth on ROA is negative although insignificant. This means that the increase in capital expenditure growth is not followed by the increase in ROA. This may be because firms are not efficient enough in utilizing the fixed assets so that the additional benefit cannot cover the costs. By employing additional debts, firms must pay a higher interest so that this will reduce firms' ROA. Nevertheless, the level of DER seems still in the safe level so that the benefit of adding debts can offset the firms' debt costs. Hence, DER weakens the negative effect of capital expenditure growth on firms ROA. In other words, DER reduces the magnitude of the negative effect of capital expenditure growth on firms ROA.

\section{Effect of Receivable Turnover on ROA Moderated by DER}

The statistical results show that receivable turnover that is moderated by DER has a negative and significant effect on ROA. This result shows that DER weakens the positive and significant effect of receivable turnover on ROA. This means that the use of debt will have a moderating effect on the receivable turnover on firms ROA. The rate of receivable turnover depends on how 
fast the period of payment of the receivables that the firms will receive. The faster the payment period will have a positive impact on the firms' profitability. However, the influence of accounts receivable which was initially able to increase the firms' profit with the existence of debt will weaken the positive influence of accounts receivable on ROA. This may be because receivable turnover is based on the receivable account of firms in which the account is classified as the current account. Conversely, DER used in this research is measured as total costs. This implies that firms also use not only short-term liabilities but also use long terms debt to finance their receivable accounts. As it is explained by Rokhmawati (2016) that the utilization of a large portion of long terms debts to finance working capital will reduce risks of firms liquidity and this lower risks will be followed by the lower benefits. Hence, DER has weakened the positive effect of receivable turnover on ROA may be because firms adopt a conservative approach to finance their working capital, where conservative approach suggests firms use many sources of funding from long terms of funding such as long terms debts. The consequence of using such long terms debt to finance firms' working capital is the lower liquidity risks. Nevertheless, the lower the risks lead firms to get a lower return. Accordingly, DER will reduce the magnitude of the positive effect of receivable turnover on ROA. In other words, DER will weaken the positive effect of receivable turnover on ROA.

\section{Conclusions and Suggestions}

\section{Conclusion}

The results of this study indicate that sales growth and capital expenditure do not affect firms' ROA. Receivable turnover has a positive and significant effect on ROA. DER has a positive and significant effect on ROA. DER cannot moderate the influence of sales growth on ROA. DER is able to moderate the effect of capital expenditure on ROA. DER is able to moderate the effect of receivable turnover on ROA.

\section{Suggestion}

For further researchers, it is expected to re-examine other factors that affect firms' ROA, because in this study the independent variables used were only sales growth, capital expenditure growth, receivable turnover, and DER as moderating variables. It is also expected to use more diverse proxies in identifying improvements in the firms' ROA in order to obtain more perfect results. For firms, they should really utilize the assets owned by the firms in order to improve their ROA.

\section{References}

Adhinegara, B. Y. (2017). Sektor Industri Minim Dukungan. Retrieved March 19, 2018, from http://www.koran-jakarta.com/sektor-industri-minim-dukungan

Ainiyah, Q. (2016). Pengaruh Perputaran Piutang, Perputaran Persediaan Dan Debt To Equity Ratio Terhadap Profitabilitas. Jurnal Ilmu dan Riset Manajemen, 5(1).

Andrian, J. (2012). Pengaruh Struktur Modal, Pertumbuhan Perusahaan, Capital Expenditure Dan Insentif Manajer Terhadap Nilai Perusahaan Dengan Profitabilitas Sebagai Variabel Intervening. Jurnal Bisnis Strategi, 21(2), 18-39.

Aprilia, E. (2017). Pengaruh Perputaran Piutang, Persediaan Dan Modal Kerjaterhadap Profitabilitas Tekstil Dan Garmen. Jurnal Ilmu dan Riset manajemen, 6(4).

Asror, M. H. (2016). Pengaruh Kebijakan Perusahaan Dan Human Capita lterhadap Nilai Perusahaan Dengan Kinerja Perusahaan Sebagai Variabel Intervening (Studi Empiris Pada 
Perusahaan Consumer Periode 2010-2012). Manuscript. Fakultas Ekonomi dan Bisnis Universitas Muhammadiyah Surakarta, Indonesia.

Barus, A. C., \& Leliani. (2013). Analisis Faktor-Faktor yang Mempengaruhi Profitabilitas pada Perusahaan manufaktur yang Terdaftar di Bursa Efek Indonesia. Jurnal Wira Ekonomi Mikroskil, 3(2), 111-121.

Brigham, E. F., \& Houston, J. F. (2016). Fundamentals of Financial Management. Boston: Cengage Learning.

Donaldson, G. (1961). Corporate debt capacity: A study of corporate debt policy and the determination of corporate debt capacity. Boston: Division of Research Harvard Graduate School of Business Administration.

Ghozali, I. (2016). Aplikasi Analisis Multivariate dengan SPSS. Semarang: Badan Penerbit UNDIP.

Hazmi, N. A. (2017). Pengaruh Penggunaan Hutang Dan Kinerja Keuangan Terhadap Profitabilitas. Jurnal Ilmu dan Riset Manajemen, 6(5).

Ikatan-Akuntan-Indonesia. (2007). Standar Akuntansi Keuangan. Jakarta: Salemba Empat.

Ilma, W., Amin, M., \& Afifudin. (2018). Analisis Pengaruh Tingkat Kenaikan Penggunaan Capital Expenditure Terhadap Kinerja Perusahaan (Studi Empiris Pada Perusahaan Manufaktur Yang Terdaftar Di Bursa Efek Indonesia 2014-2016). Jurnal Riset Akuntansi, 7(3), 108-118.

Indonesian Stock Exchange. (2017). Laporan Keuangan dan Tahunan. Retrieved October 26, 2017, from IDX: Bursa Efek Indonesia, Laporan Keuangan dan Tahunan, http://www.idx.co.id/perusahaan-tercatat/laporan-keuangan-dan-tahunan/

Jatismara, R. (2011). Analisis Pengaruh TATO, DER, Dividend, Sales, dan Current Ratio terhadap Return on Asset studi pada perusahaan manufaktur yang terdaftar di BEI tahun 2008-2010. Thesis. Semarang, Central Java, Indonesia: Universitas Diponegoro.

Kalungan, T. R., Ilat, V., \& Gamaliel, H. (2017). Perlakuan Akuntansi Capital Expenditure Dan Revenue Expenditure Pada PT. Putra Karangetang. Jurnal Riset Akuntansi Going Concern, 12(2), 1044-1054.

Kasmir. (2010). Analisis Laporan Keuangan. Jakarta: PT. Rajagrafindo Persada.

Kementerian Perindustrian. (2013). Manufaktur Ditopang Sektor Barang Konsumsi. Retrieved November 17, 2017, from Indonesia Finance Today: www.kemenperin.go.id/artikel/7014/Manufaktur-Ditopang-Sektor-Barang-Konsumsi

Keown, A. J., Martin, J. D., Petty, J. W., \& Scott-Jr, D. F. (2010). Manajemen Keuangan. Jakarta: PT. Indeks.

Myers, S. C., \& Majluf, N. S. (1984). Corporate financing and investment decisions when firms have information that investors do not have. Journal of Financial Economics, 13(2), 187221.

Nugraha, P. S., \& Haryanto, A. M. (2016). Analisis Pengaruh Sales Growth, ROE, Size, TATO, Dan Current Ratio Terhadap ROA Dan ROA Terhadap Beta Akuntansi (Accounting Beta) (Studi Kasus Pada Perusahaan Manufaktur Yang Terdaftar Di BEI Periode. Diponegoro Journal of management, 5(1), 1-12. 
Penrose, E. (1959). The Theory of the Growth of the Firm. Cambridge, U.K: John Wiley.

Rokhmawati, A. (2017). Do Financial Constraints Moderate the Impact of Financing Decisions From Internal-financing Sources on Investment. Jurnal Keuangan dan Perbankan, 21(3), $331-343$.

Rokhmawati, A. (2016). Manajemen Keuangan. Yogyakarta: Deepublish.

Rozuli, I. (2017). Sektor Industri Minim Dukungan. Retrieved March 19, 2018, from Koran Jakarta: http://www.koran-jakarta.com/sektor-industri-minim-dukungan/

Sari, N. M. (2013). Analisis Pengaruh Leverage, Efektivitas Aset Dan Sales Terhadap Profitabilitas Serta Dampaknya Terhadap Nilai Perusahaan (Studi Pada Perusahaan Di Sektor Industri Barang Konsumsi Yang Terdaftar Di Bursa Efek. Thesis. Fakultas Ekonomi dan Bisnis Universitas Diponegoro. Semarang. Indonesia.

Untara, A. P. (2014). Pengaruh Modal Intelektual Terhadap Kinerja Keuangan Perusahaan Perbankan Yang Terdaftar di BEI. Jurnal Ilmu dan Riset Akuntansi, 3(10).

Wahyuni, S. (2012). Efek Struktur Modal Terhadap Profitabilitas Pada Perusahaan Manufaktur Yang Terdaftar Di Bursa Efek Indonesia. Management Analysis Journal, 1(2), 29-33.

Wibowo, A., \& Wartini, S. (2012). Efisiensi Modal Kerja, Likuiditas dan Leverage terhadap Profitabilitas pada Perusahaan Manufaktur di BEI. Jurnal Dinamika Manajemen, 3(1), 49-58. 